\title{
AFRICAN ZIONISM AND ITS CONTRIBUTION TO AFRICAN CHRISTIANITY IN SOUTH AFRICA
}

\author{
Kelebogile Thomas Resane \\ Department of Historical \& Constructive Theology \\ University of the Free State
}

\begin{abstract}
The paper highlights the historical development of African Zionism, with special reference to the four major messianic churches. Socio-political conditions and other factors contributed to the formation of African Zionism. Israel's nationalist theology of the temple and the John Alexander Dowie's Zion City concepts played a significant role in influencing the formation of African Zionism. The churches selected for the study are Zion Christian Church, Shembe's AmaNazaretha, International Pentecost Church, and St John's Apostolic Faith Mission. The focus is on the spiritual significance of the cultic centre as perceived by these church formations. The reasons for pilgrimages to the centre are elaborated on, and the contribution of these churches to African Christianity are highlighted.
\end{abstract}

Keywords: Zionism; Church; Cultic; Messianic; Worship; Healing

\section{Introduction: Israel's nationalist theology influenced African Zionism}

The period 597-450 BCE was an era of theological crisis in Israel. Theological trends were syncretic and called for renewal of the fundamentalistic return to the messianic tradition. Three loci that held this nationalist theology were the city, the temple, and the Davidic royal throne. They were the three sacrosanct forces that held the nation together. This paper pays special attention to the cultic centre i.e. the temple. "The nationalist theology was so strong, and so deeply rooted in Israel's faith, as to be virtually unassailable" (Le Roux 1987:104). This theology proclaimed God's unconditional salvation, the irrevocability of David's dynasty, and the inviolability of God's palace (the temple) which is the symbol of God's everlasting presence in the city (Jerusalem) where David rules as king. The temple in Jerusalem was God's address. "While this was not God's exclusive or even primary residence, it was the address God gave Israel for divine encounters" (Carvalho 2008:126).

The temple as a cultic centre was a convergence point of the nation where sacrificial rituals were performed for the renewal of believers' faith in the God of Israel. There was a close bond between the temple and the palace, the altar and the throne. "The Jerusalem temple was not only royal property, but with the palace formed a single complex" (Albertz 1994:128).

After the division of the kingdom of Israel, one fundamental factor was the cultic centre. Jeroboam realised that allegiance to his dynasty (the Northern Kingdom) could be weakened when his subjects paid a visit to the cultic centre in Jerusalem, which fell in the kingdom of Judah. This is attested to by the exclamation: 
If these people go up to offer sacrifices at the Temple of the Lord in Jerusalem, they will again give their allegiance to their lord, Rehoboam, king of Judah. They will kill me and return to Rehoboam king of Judah. (1 Kings 12:27)

He established an alternative centre between the borders of the two territories i.e. Bethel, hoping "to develop an archaizing alternative to the state cult of Jerusalem, with all its innovations, which would strengthen continuity with conditions existing before the state" (Albertz 1994:143). Festivals were also held at the centre so that people could appropriate Zion experiences like before, though in another location. Indeed, Jeroboam I "established in the Northern Kingdom an annual festival, modeled to some extent after that in Jerusalem ..." (Walker 1963:309). To a certain extent, his motives were personal and political, not religious (De Gruyter 1999:291).

The cultic centre refers to a holy place, a shrine, or a destination of the saints. It is a headquarters of a movement that is often regarded as a holy site. The site is often identified as a sacred mountain or a fountain of life, sometimes both. In the religious movement researched here, the cultic centre is sometimes referred to as Zion City or the New Jerusalem.

African Zionism has a high regard and reverence for the cultic centre. The movement may differ in functions, yet at the deepest level these are congruent (Sundkler 1976: 314). For instance:

- Shembe had his first vision on the mountain, Inhlangakasi. His followers relate to two mountains i.e. Inhlangakasi and Ekuphakameni.

- George Khambule found some of his sacred stones for sanctifying people on a mountain.

- Elias Vilakazi of Swaziland lived on the mountain for three years, preaching to a tribe of "small people".

- Timothy Cekwane and his followers saw the star with a long tail on the Drakensberg - the centre of their annual pilgrimage.

- Both Daniel Nkonyane and Paul Mabiletsa of Zion confirmed the practice of regular pilgrimages to seclusion on the mountain, to return with renewed spiritual strength.

The followers or the devotees' lives revolve around this Zion. The bottom line is, "Outside of Zion is chaos and disorder" (Kiernan 1974:87). Zion is where community exclusiveness is experienced. This exclusiveness is upheld by ritual symbols and moral codes derived from or enhanced by pilgrimage to the cultic centre on a regular basis.

The four traditions studied in this paper show the historical and spiritual significance of these centres. Annual or regular pilgrimages to the centre are undertaken with the expectation of a higher spiritual experience and the fulfillment of faith. Centres are regarded as holy ground, as a meeting point with the divine figure (prophet, bishop, pastor) who is always esteemed as being endowed with messianic authority.

\section{Identity of African Initiated Churches}

African Christianity branched off from mainstream Christianity after the missionary pioneers from the West planted churches on African soil. It is a significant Christian phenomenon, a force to be reckoned with in church-historical, theological and missional 
studies. The aim of this paper is to show the affinity of this African Christianity with the Zion theology of the Old Testament where everything deistic revolves around a shrine or a cultic centre. Like the Old Testament Jews, the African Indigenous Churches strive for a "quest to 'indigenize', to establish a new African Christian identity" (Pretorius and Jafta 1997:212).

African Initiated Churches are churches pioneered by Africans either as a reaction to established Christianity or based on a voluntary or divine revelation commission. This phenomenon can be traced from the 1880 s to the present. It is an unavoidable and realistic phenomenon in Christian history studies in South Africa. Makhubu (1988:5) defines this phenomenon as "... a purely black-controlled denomination with no links in membership or administrative controls with any non-African church... churches that have completely broken the umbilical cord with the western missionary enterprise"

Sundkler's (1976:15) identification of these churches as Zion provides a sociohistorical definition, offering the rationale behind the emergence of these churches:

Zion forms one large group, or family, of churches in the prolific world of "African Independent Churches". In a South Africa dominated by white caste and colour, some of the African leaders felt that they could not stand this dominance any longer. They decided to strike out on their own and form their very own religious organizations, apart from the European-led mission churches.

Like in all organisational categories, African Independent Churches is segmented into several categories. Stinton (2004:39) describes it as

a broad category covering everything from cultural forms of life and arts, to family and communal life, to the struggles against racism, sexism, and any other form of economic, political, social, and cultural oppression.

Resane (2017:179-190) categorises it according to conglomerates: Ethiopian, Messianic, Zionist, Apostolic, and Charismatic. Generally, African Independent Churches is a Christian religious movement in a modern African society embracing the deeply religious disposition which is the foundation of African religious experience. The movement is observed in diverse practices and paraphernalia including uniforms, and symbols of authority (sticks, iron rods, water etc.). Despite proliferations and diversities within these groups, they all emanated from the same socio-historical rationale. Historical analysis of the emergence of African Christianity demonstrates that African leaders found western Christianity inadequate in terms of promoting African leadership capacity or found the socio-cultural contours irrelevant, which led to its establishment (Roy 2017:104).

This study selects four of these churches in South Africa and examines their cultic centres: Zion Christian Church in Moria, Shembe's Ekuphakameni, International Pentecostal Church's Silo, and St John's Apostolic Faith Mission of Christina Nku's Evaton Church of the Twelve Doors, known as the Temple. 


\section{Zion Christian Church in Moria}

The first and prominent Zionist church with a cultic centre is Zion Christian Church (ZCC). The founder is Engenas Lekganyane who seceded from Zion Apostolic Faith Mission in 1925 (Roy 2017:135). In 1930, Lekganyane bought a farm east of Pietersburg (today Polokwane) and named it Moria, which thereafter became the place of pilgrimage for ZCC members (Anderson 2004:108). The place carries some spiritual significance where the devotees connect with God. Moria is the cultic centre - a holy site where devotees converge and bring their votive offerings and perform cultic ceremonies under the guidance and directions of spiritual leaders (Rosen 1988:115). Moria is a destination of pilgrims at least twice a year - Easter weekend and the first weekend of September, considered the birth date of the ZCC.

\section{Shembe's Church of the Nazarites: Two cultic centres}

The majority of the members of the Shembe Church (iBandla la MaNazaretha) are of the Zulu ethnic group. The church has a strong spiritual and emotional attachment to its holy spaces or sacred sites. The Shembe's Zionistic ideals are realised at the two unrivalled mountains (holy mountains) in Ohlange near Durban, known as Ekuphakameni, and Inhlangakazi, $120 \mathrm{~km}$ away. Ekuphakameni ("the elevated place") is known as the Zion of the church, a holy place. It was established in 1911 and became the headquarters of Shembe's prophetic operations. Through divine revelation, Shembe went to Inhlangakazi in 1912 and again in January 1913 when "he took his flock with him on a pilgrimage to the Holy Mountain, there to stay together for two weeks, living in temporary shelters, built anew for each occasion" (Sundkler 1976:167-8). The founder of the Shembe Church, Isaiah Shembe, was also the first to complete the Shembe pilgrimage to the Holy Mountain (Nhlangakazi), as God summoned him to the mountain in 1916 (Roy 2017:139).

There are two pilgrimages per year for the faithful and adherents. One is the January Feast of Tabernacles on Inhlangakazi mountain, and the other the great festival in July at the Ekuphakameni headquarters. The July festival offers an opportunity for Shembe to explain the teachings of the church (Sundkler 1976:168-9).

\section{Modise's International Pentecost Church: Silo}

Of the four Zionist traditions discussed, sources on the history of the International Pentecost Church (IPC) are most scant. Literature on this tradition is not abundant, but physical structures and press statements tell the story. Rev Frederick S Modise founded the church in 1962, seceding from the ZCC. Its headquarters is at Zuurbekom, west of Soweto in Gauteng province. The cultic centre is known as Silo - a complex of buildings worth millions of rands, including an auditorium seating 20000 people and a wellequipped restaurant to feed the multitudes who flock there once a month to be healed by "Father Modise".

The origin of the name "Silo" lies in apocalyptic experiences of Modise. Anderson (1992:110) offers information on these revelations received on 12 September 1962:

He saw a house with a thatched roof and he was told to climb on the rafters. There he saw a great crowd of people of all races kneeling down and praying, facing the east... This place, he later told us, was Silo. 
Anderson continues that it was also through this vision that Modise received healing, and was given instructions on how to pray spiritually. He was discharged from hospital on a Saturday (3 October 1962); and according to the divine visitation this day was decreed as Sabbath. For this reason IPC, like Shembe's AmaNazaretha Church, is Sabbatarian regarding its day of worship (1992:111).

IPC is one of the largest and fastest growing African indigenous churches, and possibly the closest example of a "Messianic church" in South Africa today. Silo was officially opened in May 1991 by the then President FW de Klerk. To capture the liturgy at Silo cultic centre, Anderson's (1992b:7) field research in Soshanguve near Pretoria and Silo in Zuurbekom, states:

In the front of the huge auditorium at the church headquarters at "Silo" (Zuurbekom), there is a throne-like chair in front of an altar-like table on which there is a round seven-globed table lamp. Modise explained to the visitors at Silo the meaning of the lamp: the centre red globe which stands higher than the others represents fire (which in IPC theology is the name for God - see below), and the six smaller lamps surrounding it are the Water, the Blood and the Spirit of Truth (the three witnesses of 1 John 5:7-8), the Father, the Son, and the Holy Spirit. This lamp is only switched on when Modise is present at the table. Modise sits on the large chair, often dressed in his high priest-like robe. IPC ministers at Silo wear red robes, similar to an academic gown. From sunset on Friday until Sunday morning Modise fasts and spends much of the time in the auditorium with the crowds who come to be healed. There is a choir and an electronic band at Silo; and music forms a very important part of the services, as does the taking up of various collections - only members partake in the collections. Several collections may take place during a service; and members are encouraged to give liberally, even up to an entire wage.

This research shows that IPC is coloured with elegance and symbolism that needs interpretation for spiritual application and understanding.

\section{Christina Nku's St Johns Apostolic Faith Mission and the Church of the Twelve Doors}

This is one of the significant apostolic groups that trace their roots to the Wakkerstroom revivals. Christina Nku grew up as a frail, petite woman of crises. She was baptised and confirmed in faith in the Dutch Reformed Church. During one of the crises, in 1914, she saw a vision of a huge church with twelve doors. Through divine revelation, she was informed that the building she saw was the Temple of Jerusalem on Mount Zion (Sundkler 1976:80). She and her husband consequently joined the Apostolic Faith Mission where her Pentecostal experience was confirmed, especially the baptism of the Holy Spirit that can be given even to Europeans (1976:80).

The patriarchal ideology is a set of beliefs concerning gender relations and their manifestations in institutions, including marriage, the family, and the home, where the father usually possesses absolute control over families or clans. In this ideology male ego rules supreme over societies, excluding women from positions of authority or leadership (Kobo 2019:83). Ma Nku found that patriarchy was dominating the church leadership, including church leader Pieter le Roux of the Apostolic Faith Mission, and 
that it resisted her actions under the gifts of the Spirit (1976:80). She established herself as self-appointed leader of a new religious movement, empowered by the century's successive waves of revivalism (Morgan 1999:44).

This once powerful exponentially growing African Independent Church that emerged in opposition to male patriarchy was and still is marred with a painful history of internal feuds and disputes, often in courts of law. The Temple in Evaton lost its fame and prominence in the 1970, when Bishop Petrus Masango clashed with Christina Nku. Through court battles, Masango gained legitimacy of the church leadership, and moved the cultic headquarters to Katlehong in Germiston. In her old age, with the assistance of her children and grandchildren, Ma Nku relocated her headquarters to the village of Motlollo, west of Rustenburg in the North West province. This is where she died in 1988. By then her church had been renamed St Johns Apostolic Church of Prophecy, while Masango's seceded group retained the original name. The spiritual significance of Motlollo has not yet manifested like that of Evaton. The church in Evaton is led by Rev Daniel Mathe, the grandson of Ma Nku. According to a legal advisor of the church, Rev Mbulelo Phetheni: "Motlollo is an international headquarters, while Evaton is a national headquarters" (telephonic interview August, 2017). It seems that factions within the St Johns Apostolic Faith Mission have lost spiritual connectedness with any cultic centre. The original enthusiasm accompanied by healings seems to have subsided since the centre no longer attracts many seekers as in the past.

\section{The socio-political events: Springboard of Zion Cities}

African Zionism is mainly the result of socio-economic changes that were shaping the South African socio-political landscape of the $19^{\text {th }}$ century. After the population migration towards the emerging city centres due to discoveries of diamonds and gold, the African traditional life deteriorated. This escalated especially between the two world wars when African life took a new shape in mine compounds, overcrowded locations, or slum yards (Pretorius and Jafta 1997:217). Industrialisation and urbanisation swelled, dislodging people from their roots and traditions, encouraging Africans to embrace westernisation and Christianity by abandoning their socio-cultural religious roots. This was met with resistance and rebellion in certain quarters. Brown (2005:94) substantiates this:

Gradually this invasion by foreign whites and acculturation pressures, i.e. forcing people to speak English and obey English laws and customs, caused Zulu, Xhosa and other African people to experience psychological stress while their culture was under constant attack. The African response was that crime, alcohol abuse and lawlessness rose to frightening levels due to anomie and normlessness.

The African National Congress (ANC) and the Industrial and Commercial Workers Union engaged religion to address this African social plight. This led to the emergence of Zion City churches, especially in urban areas. These churches branded themselves with the name "Zion" as a symbol of the New Jerusalem. Events in Wakkerstroom and urban centres were dynamic, a new phenomenon was unfolding that influenced Christianity in South Africa on a large scale. For instance, one of the leaders, Daniel Nkonyane "introduced certain elements in worship: white robes, bare feet, holy sticks, 
and Old Testament symbolism ..." (Pretorius and Jafta 1997:218). These constitute the characteristic features of Zionism today.

In the meantime, the mission churches were flourishing in emerging mining centres like Johannesburg and Kimberley, though with some paternalistic tendencies that contributed to the attitude of supremacy of white missionaries who disregarded the emerging African church leaders. These missionaries were in control of the church governance and polity in all structures and patterned themselves according to Western church polity (Pretorius and Jafta 1997:213). The missionaries collaborated with the government to confiscate land from the indigenous people.

Motlhabi (2008:38) points out that African Initiated Churches' secession from the mainline churches was not just political and economic. It was also theological and cultural, because:

They sought freedom both from 'an oppressive church situation' and 'from deculturizing, de-Africanizing, detribalizing treatment, and reacted...against a foreign, unadapted, western-oriented church which [did] not take note of the African approach and worldview.'

The developments expressed above indicate that Western Christianity was not reaching or fulfilling the deep spiritual needs of Africans. Africans who seceded to form African Zionism needed something spiritually significant. They needed something "emphasizing revivalism that, through the 'African worldview' seeks to address Africans' authentic need for deep spirituality and religiosity" (Akoto-Abutiate 2014:146).

This opens a wide field of research that leads to the contribution of these churches in shaping the current South African socio-cultural space. Much had been done, yet the researched knowledge is still unpublished in the public domain as expressed by Kiernan (1974:80) decades ago:

The view that African Independent Churches are primarily a reaction to White rule is thus a theme which is strongly entrenched in the literature on the subject and represents a respectable body of opinion.

The fact remains that African Zionism or African Independent Churches, and the African traditions or African worldview are irreversibly symbiotic. Theron (1996:14) points out:

The whole of life in its aspects - politics, economy, family relations, marriage, social relations, culture, customs - everything is permeated with this religious world view of the African.

\section{The South African Zionism and cultic centres}

This paper focuses on the branch of African Christianity called Zionism. These indigenous spiritual churches emanate from the Christian Catholic Church in Zion founded by American John Alexander Dowie. Dowie established the headquarters of his theocracy in Zion City in Illinois, which became a safe haven for faithful and ascetic Zionists. According to Anderson (2004:32): 
This theocracy sought to be a classless, pacifistic society, was committed to racial and gender equality, sent missionaries overseas, encouraged interracial marriages and supported the disadvantaged.

Its first missionary to Africa in 1897 was Rev J Buchler. His missionary endeavours were in partnership with Dutch Reformed Church missionary Pieter le Roux, operating from Wakkerstroom. The two parted ways due to doctrinal differences and Le Roux pioneered the Apostolic Faith Mission as it is known in South Africa today (Anderson 2004:106).

Dowie's dogma was oriented to divine healing, baptism of adults by immersion in the name of the Trinity, and a belief in the imminent return of Christ. Le Roux's influence later added two doctrinal tenets of baptism by the Holy Spirit and speaking in tongues (Pretorius and Jafta 1997:217). The ascetic practices in those days as with the Pentecostals included prohibition of alcohol intake, smoking, and eating pork (Anderson 2004:108).

\section{What happens at the cultic centre?}

African Zionism revolves around the pioneer or the founder, who always establishes a cultic centre. The mystic way of discovering or identifying the centre differs from situation to situation. What matters most is that

Realistically, no religion that exists can be without its leaders because, they are the ones who are the intermediaries between the deities and their people. It does not matter what names they have or what kind of duties they assign them, religious leaders have the grave duty of interpreting the messages of their deities to their followers. (Mawusi 2015:98)

These pioneers of the new order determine by divine revelation their authenticity, calling, and mandate. This also directs the rationale behind the regular pilgrimages to the shrine or a cultic centre.

The first observation is that the mountaintop experience is the place of divine revelation, or religious ideology and power, hence Shembe could exclaim: "I have seen Jehova". It has been a place of encounter with the Holy One. The pilgrim will consequently see new visions and return a different person (Sundkler 1976:315). According to popular belief God spoke to Isaiah Shembe as he did with Moses at Mount Sinai. As a feature of religious ideology, Ekuphakameni has become home to the most sacred shrines and is where holy water is kept for ceremonies.

The mountain pilgrimage experience ushers in a sense of nearness to God, where one experiences God's holy presence. Some ascetic aspects such as fasting and purification always accompanies this. The result is renewed strength. Sundkler's (1976:315) words enrich one's understanding here that

To the ordinary follower in the crowd, the Mountain fast, along with the Fountain plunge, served to integrate the personality, the more so that he or she had often encountered Mountain and Fountain in the realm of the dream. 
The mountaintop experience is also accompanied by some strange apocalyptic phenomena, the common one being "the star with a long tail". For Zionist leaders like Enoch Mgijima, Isaiah Shembe, Timothy Cekwane, Job S Mtanti, and Philemon B Sibiya, this star is an "indication of the role of cosmic events for the emergence and the trend of the movement ..." (Sundkler 1976:315).

Engenas Lekganyane, the founder of Zion Christian Church, also testifies of the mountain experience where he received the revelation for pioneering the new church. While serving under Elias Mahlangu in the Zion Apostolic Church he prayed on the mountain where "he had a vision that a multitude would follow him" (Anderson 2004:107).

Christina Nku established St John's Apostolic Faith Mission and frequently visited one particular spot in Evaton for meditation and apocalyptic visions. Through divine revelation, she was instructed to build God a church with twelve doors (Pretorius and Jafta 1997:220; Anderson and Pillay 1997:232). It was at this very spot where the Church of the Twelve Doors was built. This church is known as "the Temple" and was finished in 1952. For many years, this was the largest African Independent Church building in the Pretoria-Witwatersrand-Vaal Triangle area (Anderson 1992:107).

A cultic centre is holy ground for the devotees, who seek spiritual direction and/or healing. For instance, for ZCC members, "Pilgrimage to Moria provides healing and prophecy. Like in all cultic centers in AIC, Moria is a mountain of "purifying power"' (Sundkler 1976:313). The same notion is noted regarding pilgrimages to Silo for IPC members. One should bear in mind that this is consonant with the African concept of the spirit world. Turaki (1997:41) helps us to understand this:

African concepts of reality and destiny are deeply rooted in the spirit world. The laws of spiritual mystery govern all social and spiritual phenomena.

People converge at the centre for healing. A good example is that of the St Johns Apostolic Faith Mission of Ma Nku, who was considered a water healer. Outside the church building there is a fountain where triune immersions baptisms take place. Anderson (1992:106) also confirms, "She prayed over water in thousands of bottles and buckets, which thus received healing power to be used by the faithful."

Like the ZCC and IPC, the St John Apostolic Faith Mission was founded on healing; and this used to be one of the main emphases (Anderson and Otwang 1993:24). Convergence of the followers at the church also came through an apocalyptic vision. Landman (2006:12) states that "in 1935 [Ma Nku] was told to have her own church conferences three times a year that is, in March, August and November". These annual gatherings drew thousands of people who testified "... that they were there because of having been healed by this woman, or because they were awaiting their opportunity for her healing touch" (Sundkler 1976:81).

For ZCC followers, Moria is associated with issues of health and procreation. Seekers are given ditaela (injunctions) through the prophets for their needs. Wepener and Barnard (2016:83) point to this fact:

One researcher was told that he has an illness, specifically a lung disease and at another time also that he suffers from headaches. Both these maladies will however 
disappear if he follows certain injunctions. Several prophecies were also related to fertility and being blessed with children.

Anderson's research shows that healing and worship are central to regular visits to the centre. During this field research, the field workers (1992:9) determined that:

At Silo, the liturgy is somewhat similar, but on a much larger scale. On the weekend our field worker attended, the visitors who arrived were directed to queue in the basement of the auditorium to have their personal particulars and sicknesses written on forms, after which they received cards with numbers on it. Our field worker had to be "sick" in order to be admitted.

These findings and conclusions correlate with those of Pretorius and Jafta (1997:223) that the ministry of healing is probably the most profound aspect of their spirituality.

It is a normal practice of both ZCC and IPC for the doors of the centres to be open for seeking or worship. The doors may be closed during healing and praying sessions, but are opened during preaching sessions. Kiernan elaborates on this practice (1974:82-84). Silo cultic centre is likewise holy ground for devotees who seek spiritual direction and/or healing. However, it should be noted that Modise practices healing the sick without using any symbolic objects such as those found in other Pentecostal-type churches (Anderson 1992a:160). "These things he describes as 'idols', which he was told to throw away at his 'conversion' on 3 October 1962" (Anderson 1992:9).

It can also be noted that pilgrimage to the cultic centre is the endorsement of loyalty to and membership of the community. The pilgrimage to Moria seems to consolidate membership, as Wepener and Barnard (2016:83) observe: "Related closely to the theme of going to Moria is the theme of joining the church." The same notion can be noted of the IPC. Anderson and Otwang (1993:24) in their research found that "it appears that a person who receives healing from Modise has extreme pressure thereafter to join the church, and usually does".

The cultic centre is the point of encounter with the messianic figure. As in African traditional religions, these messianic figures are viewed as moral analysts of the community, and their function is to contribute to the maintenance of balance and harmony. They are the prophetic figures who arise to call people back to a new kind of life (Thorpe 1991:116). For the faithful, to behold the messianic figure is to connect spiritually and a spiritual privilege. It is the centre where the community gathers and experiences heaven in unison. To see the spiritual leader (messiah) transcends and translates a devotee to a particular and mystical spiritual level. For African Zionists, the centre that is compared to Mount Zion is an encounter with the divine. In contrasting Mount Sinai and Mount Zion, Ramantswana (2013:5/6) reports what a Zionist may claim to experience at such a spiritual centre:

The atmosphere at the heavenly Mount Zion is inviting and welcoming, whereas the picture of Mount Sinai is uninviting. To come to heavenly Mount Zion is to come to a populated mountain in contrast to the uninhabited Mount Sinai; it is to come into the company of the other worldly, the company of angels; it is to come into contact again with the familiar, God's firstborn children, whose names are 
written in heaven, the righteous ones; it is to come into the presence of his majesty, King Jesus, who sits in the place of honour at the right hand of God as a mediator of the new covenant.

This leads one to the inevitable conclusion of reflecting on the purpose of religion in the African worldview. The messianic figure is a centripetal force at the cultic centre. This messiah imparts blessings and material well-being to the devotee, as a way of enhancing one's mystical connection with the divine. Gehman (2005:87) describes it thus:

The chief purpose of religion in African culture is to acquire greater life- force from the other higher beings and lesser creatures or objects in order to enhance health, wealth and status in life.

For instance, at Silo, Modise sits on the large chair, often dressed in his high priest-like robe. Anderson (1992:113) affirms, "There is undoubtedly a personality cult centring on Modise, whose picture appears above the 'altar' in the centre of the auditorium..." In Moria, Lekganyane's addresses reverberate and echo thunderously to the followers from the hilltop, conspicuously through an electric screen and a powerful public address system. $\mathrm{Ma} \mathrm{Nku} \mathrm{was} \mathrm{always} \mathrm{seen} \mathrm{in} \mathrm{her} \mathrm{blue} \mathrm{and} \mathrm{white} \mathrm{uniform} \mathrm{interacting} \mathrm{with} \mathrm{the} \mathrm{devotees.}$ Phetheni told me that she justified this conduct by explaining that "she was not a pastor or a bishop, but a prophet. A prophet is among the people, not above or ahead of them". The striking difference is that visiting Ma Nku's shrine in Evaton was for personal needs more than an encounter with the "messiah".

Unfortunately, this beholding of the messianic figure is generally not questionable. The position, prestige and privilege of these leaders are infallible. A leader can easily turn into a lifelong oppressor of the ecclesial community, effectively de-christianising it. He or she can behave like someone " ... who cannot be corrected 'from below', since their very vices and mistakes are presented as 'holiness' and offered to the people as virtues to be imitated" (Bujo 2006:98).

This is a cautionary highlight, but it is not salient in most of the pioneers highlighted in this paper. The second and the third generations after their departures are often the ones who fall into this moral conduit.

The iBandla la MaNazaretha, the pilgrimage takes three days to travel the $80 \mathrm{~km}$ from Ebhohleni to Nhlangakazi. Wearing pure white robes, the members of the Shembe Church walk along the path to the Holy Mountain singing praises. Once at the mountain, the followers perform worship dances and reflect on their religion and beliefs, creating a holy site, a place of spiritual reflection and a retreat. Pilgrims regard this participation as the point of impartation of blessings upon their lives.

This illustrates that African Zionists consider the cultic centre a focus for experiencing freedom to celebrate the goodness of God with all their viscera. However, such a centre can contribute to atrophying devotees' celebrative and imaginative faculties. A caution by Muthengi (Ngewa, Shaw and Tienou 1998:257) is that, "The issue here is not this or that mountain or church building, but how should the true worshippers approach the true and living God." Conservatively speaking, the expression of spirituality and celebratory worship cannot be dependent on places and things such as shrines, altars, fountains, or even a mountain. However, in African spirituality, gathering around the shrine is a celebration 
that adds a note of gaiety, festivity, hilarity, and deeper experience of exhilaration (Foster 1985:169).

\section{The contribution of African Zionism to African Christianity}

The invaluable contribution of this branch of Christianity is described by Pretorius and Jafta (1997:224-226; Anderson 1992:119-120). These authors elaborate on the role of these African Zionists as a catalyst for the emergence of the new society regarding their political and social impact during the socio-political marginalisation of Africans in South Africa.

The first contribution of African Zionism to Christianity is the preservation and perpetuation of indigeneity. At the heart of Zionism, worship is practised according to cultural style. The songs are in the people's languages, including choreography and general negritude. By negritude is meant "the totality of the black experience - the culture, values, and especially the spirit of black African civilisation" (Coetzee and Roux 2000:450). Africans experience connection with God in different ways than Westerners. As Eastern people, for them worship is emotional - the whole being is involved (body, soul and mind).

God calls for worship that involves our whole being. The body, mind, spirit, and emotions should all be laid on the altar of worship. Often we have forgotten that worship should include the body as well as the mind and spirit. (Foster 1985:147)

Wepener and Barnard (2016:77) detail their experiences at the ZCC worship, describing the mokhukhu (khaki clad men regarded as protectors of the congregation) stamping their feet and jumping simultaneously, resulting in deep sonorous sound accompanied by vibrating ground. The whole body and being is involved in worship. In traditional churches influenced by the West, worship, even through singing, disengages physical expression and rarely invoke emotions. In fact, in Western Christianity emotionality is associated with demonic expression during worship. Pretorius and Jafta (1997:223) remind us that African Christians embrace a livelier and emotional worship with liturgy accompanied by extempore prayers, uniforms, drums, dancing, and symbolic instruments.

Switching on to any African radio station in South Africa, a listener is confronted with Afro Christian music, popularly referred to as Gospel music, such as the IPC choir. They sing traditional hymns with the same lyrics, but with tempos and gusto that synchronise with African rhythms. Realistically, contemporary Afro Gospel music derives its roots and influence from African Zionism. Many mainline churches including the Roman Catholic Church have embraced Afro Gospel music expressions in diverse ways. They have incorporated hand clapping, cushion cymbals, drums (traditional and Western), trumpets (vuvuzelas), ram horns, and bells in their worship in order to assert their African-ness in worship. Foster (1985:147) notes that, "Standing, clapping, dancing, lifting the hands, lifting the head are postures consistent with the spirit of praise." Regardless of all these physical and emotional expressions or instrumentations applied, the bottom line remains: "African Christian music should be theologically sound and African in tune" (Muthengi 1998:259). Thanks to African Zionism!

African Zionism also contributes immensely to synchrony and the rudiments of pastoral care. For them this is not the content of a Practical Theology module, but a practical lifestyle. Zionists live like a community where life is experienced. They gather around each other during times of crisis and celebration. Visiting the sick in hospital or at home is 
spontaneous, not just a mandate. In times of celebrating new birth, achievement, or any excellent opportunity for a member, Zionists rally around the member and engage in the discipline of celebration. This is communion ecclesiology at its best.

Character development through discipline is another contribution of African Zionists to Christianity. All formations of African Zionism practise the disciplines of abstinence from the destructive intake of alcohol, smoking and eating pork. Anderson (1992:120) concludes his research by highlighting that "they also spurn the use of beer and tobacco". This is not sheer asceticism, but a disciplined life of self-control towards character development. It is not just a rhetoric, but a religious system aimed to produce its own kind of morals and ethics (Turaki 1997:43). It is moral responsibility upholding traditions, customs, and taboos as a way of maintaining harmony and peace in communities (NkasahObrempong 2013:29). For many Africans, rules and values are important for affirming self-hood and societal good.

Another contribution of African Zionism to African Christianity is its inclusive ecumenism. African Zionists subliminally embrace goodwill expansion beyond denominationalism inclusive of other churches. This synchronises with the biblical exhortation for unity-in-diversity. On the surface, this may sound like crying for umbrella fraternities, but history has proven this does not work well. For African Zionists, this is an appeal for an ecumenical attitude in their Christian convictions (Mutunga 1977:74). Currently the South African Council of Messianic Churches in Christ (SACMCC) includes churches such as Bantu Church of Christ, Nazareth Baptist Church, Twelve Apostles Church in Christ, Zion Christian Church, Ntsikane Bantu Prophet and Twelve Apostles Church in Christ. These are formations known as the Messianic Churches. Other similar formations are the South African Union Council of Independent Churches (SAUCIC), the Council of African Independent Churches, which is an affiliate of the South African Council of Churches, the Federal Council of Indigenous Churches etc. These formations aim to foster communion and ecumenical cooperation of different traditions to speak with one voice in the socio-political landscape, hence some formations that existed from the middle of the $20^{\text {th }}$ century disappeared after 1994 .

\section{Conclusion}

The cultic centre plays a pivotal role in the assertion of spirituality experienced through African expression blended with the religious outlook of Africa.

It must be acknowledged that these churches have been highly successful, and that their growth has been phenomenal. One of the reasons for this can be ascribed to their treatment of and their attitudes towards the traditional customs, thoughts and spirituality of Africa. (Theron 1996:27)

The influence of the formation of cultic centres emanated from the Zion City concept of John Alexander Dowie in Illinois, USA. This morning star of Pentecostal missions in South Africa pioneered Pentecostal mission in South Africa patterned after Zion City, which was a theocracy "with schools, stores, and factories, all controlled by Zionists, a safe haven for the faithful" (Pretorius and Jafta 1997:217).

However, the cultic centre concept was derived from biblical injunctions and references to the altar and the temple as a centre of worship, where the worshiper could 
meet God and his priests, and fellow worshippers from the other corners of the globe. The temple of Solomon in Jerusalem is particularly situated as the cultic centre symbolising the presence of God.

In African Zionism, the cultic centre is a place of revelation (mountaintop experience). This is especially common in all four formations discussed in this paper. The cultic centre is the place of spiritual direction and healing. Healing is an important rationale for pilgrimage to the centre. Furthermore, like the temple of Solomon in the Old Testament, the centre is the place of worship. This is not worship in the ordinary sense of the word, but a mystical connection on holy ground with the Supreme Being. Another reason for pilgrimage to the centre is as an expression of devotion and loyalty as a member of the community. This is particularly observed by ZCC, IPC and Shembe's devotees. For IPC and ZCC, the pilgrimage seems to be an opportunity for encounter with a messianic figure (uBaba, Bishop, Ntate etc.). The iBandla la AmaNazaretha seem to adhere to pilgrimage vigorously in order to learn and to receive special blessings.

This paper concludes with the contribution of African Zionism to African Christianity regardless of its roots of dissatisfaction with mainline Christianity from the West. It must be borne in mind that these formations' contribution should not to be considered in terms of dogmatic eloquence or synchronic blending of faith and culture. Motlhabi (2008:39) agrees that:

Their contribution is said to be found chiefly in the following aspects, among others: "in their doctrine of the spirit; in their apostolic zeal and missionary power; in their sense of belonging - a new community; in their belief in the universality of the church; in their tolerance, worship, faith healing, counselling, prophetic advice, sacramental life and symbolism, and generosity - the art of joyful giving".

One basic lesson African Christians should learn from African Zionism is that, "Authentic Christian identity is in every respect relevant to the surrounding world" (Karamaga 1993:68). It enhances Christianity through indigenous knowledge systems, especially in the area of music and worship. It offers crucial object lessons regarding pastoral care, character development, and ecumenical cooperation. Mainstream Christianity needs to be liberated from prejudice, arrogance, isolationism, and eurocentrism, and learn from African Zionism.

\section{BIBLIOGRAPHY}

Akoto-Abutiate, DB. 2014. African theology/ies: A contemporary mosaical approach. Bloomington: Authorhouse.

Albertz, R. 1994. A history of Israelite religion in the Old Testament period, Volume I: From the beginnings to the end of the monarchy. Louisville/London: Westminster/John Knox Press.

Anderson, AH. 1992a. African Pentecostalism in a South African urban environment: a missiological evaluation. DTh thesis, University of South Africa, Pretoria.

Anderson, AH. 1992b. Bazalwane: African Pentecostals in South Africa. Pretoria: University of South Africa Press. 
Anderson, A. Frederick Modise and the International Pentecost Church: A modern African messianic movement? Institute for Theological Research, UNISA. http://artsweb.bham.ac.uk/aanderson/Publications/frederick_modise_and_the_intern a.htm (Accessed 13 Jan 2018).

Anderson, A and Otwang, S. 1993. Tumelo: The faith of African Pentecostals in South Africa. Pretoria: University of South Africa Press.

Anderson AA and Pillay, GJ. 1997. The segregated Spirit: The Pentecostals. In R Elphick and R Davenport, Christianity in South Africa: A political, social \& cultural history. Claremont: David Philip Publishers/Oxford: James Currey Publishers, 227-241.

Anderson, A. 2004. An introduction to Pentecostalism. Cambridge: Cambridge University Press.

Brown, DL. 2005. Shembeism and the Rainbow Nation: Shembe religion and cultural change in Durban, South Africa, Ufahamu: A Journal of African Studies, 31(12):90-113. https://escholarship.org/uc/item/03z6b3xf (Accessed 16 Feb 2018).

Bujo, B. 2006. African theology in its social context. Eugene, Oregon: Wipf \& Stock Publishers.

Carvalho, CL. 2008. Finding a treasure map: Sacred space in the Old Testament. In CM Bechter (ed.), Touching the altar: The Old Testament for Christian worship. Grand Rapids/Cambridge: W.B. Eerdmans.

Coetzee, PH and Roux, AP. 2000. Philosophy from Africa: A text with readings. Cape Town: Oxford University Press.

Daneel, ML. 1974. Old and new in Southern Shona independent churches: Vol II. The Hague: Mouton.

De Gruyter, W. 1999. The three Biblical altar laws: Development in the sacrificial cult in practice and theology: Political and economic background. Berlin/New York: $\mathrm{GmbH}$ $\&$ Co.

Foster, R. 1985. Celebration of discipline: The path to spiritual growth. London: Hodder \& Stoughton.

Gehman, RJ. 2005. African Traditional Religion in Biblical perspective, (Rev). Nairobi/Kampala/Dar-es-Salaam: East African Educational Publishers.

IPHC, s.a. International Pentecost Holiness Church. Johannesburg: IPHC.

Karamaga, A. 1993. Selfhood of the church in Africa. In DW Waruta (ed.), African church in the 21 $1^{\text {st }}$ century: Challenges and promises. Nairobi: AACC Publishers, 65-79.

Kiernan, KP. 1974. Where Zionists draw the line: a study of religious exclusiveness in an African township, African Studies 33(2):79-90. https://doi.org/10.1080/ 00020187408707426 (Accessed $16 \mathrm{Jul} 2018$ ).

Kobo, FA. 2019. Womanism and black anthropology: In memory of James Cone, Journal of Theology for Southern Africa $162 \&$ 163:82-100.

Landman, C.2006. Christinah Nku and St John's: A hundred years later, Studia Historiae Ecclesiasticae 32(3)1-32. http://uir.unisa.ac.za/bitstream/handle/10500/4418/ Lanmdna_2_.pdf?sequence=1 (Accessed 18 Sept 2018).

Makhubu, P. 1988. Who are the Independent Churches? Johannesburg: Skotaville.

Mawusi, K. 2015. African theology: A study of African Theology within an African traditional religion, (The Eves of Ghana) and within a comparative study of Christian tradition. Victoria, BC, Canada: Friesen Press. 
Morgan, S. 1999. Feminist approaches. In P Connolly (ed.), Approaches to the study of religion. London/New York: Cassell, 42-72.

Motlhabi, M. 2008. African theology/Black theology in South Africa: Looking back, moving on. Pretoria: University of South Africa.

Muthengi, J. 1998. The work and worship of the Christian church. In S Ngewa, M Shaw and $\mathrm{T}$ Tienou, Issues in African Christian theology. Nairobi/Kampala/Dar-esSalaam: East African Educational Publishers, 245-264.

Mutunga, SM. 1977. Toward a wa kwetu without strangers. In EA Buconyori (ed.), Tribalism and ethnicity. Nairobi: The AEA Theological and Christian Education Commission, 9-84.

Nkansah-Obrempong, J. 2013. Foundations for African theological ethics. Carlisle: Langham Monographs.

Pretorius, H and Jafta, L. 1997. A branch springs out: African Initiated Churches. In R Elphick and R Davenport (eds), Christianity in South Africa: A political, social \& cultural history. Claremont: David Philip Publishers/Oxford: James Currey Publishers, 211-226.

Ramantswana, H. 2013. Mount Sinai and Mount Zion: Discontinuity and continuity in the book of Hebrews, In die Skriflig/In Luce Verbi 47(1). http://dx.doi.org/10. 4102/ ids.v47i1.90.

Resane, KT. 2017. Communion ecclesiology in a racially polarised South Africa. Bloemfontein: SunMedia.

Rosen, B. 1988. Early Israelite cultic centres in the Hill Country, Vetus Testamentum 38(1):114-117.

Roy, K. 2017. The story of the church in South Africa. Carlisle: Langham Global Library.

Shembe Pilgrimage - A spiritual experience amongst the Zulu. http://www.southafrica .com/blog/shembe-pilgrimage-a-spiritual-experience-amongst-the-zulu (Accessed 7 Dec 2017).

Stinton, DB. 2004. Jesus of Africa: Voices of contemporary African christology. New York: Pauline Publishers Africa.

Sundkler, B. 1976. Zulu Zion and some Swazi Zionists. Oxford: Oxford University Press. Rev Mbulelo Phetheni. Telephonic interview on 23 January 2018. He is the legal advisor of the St John's Apostolic Church of Prophecy.

Theron, PF. 1996. African traditional cultures and the church. Pretoria: University of Pretoria.

Thorpe, SA. 1991. African traditional religions. Pretoria: University of South Africa.

Turaki, Y. 1997. Tribal gods of Africa: Ethnicity, racism, tribalism and the Gospel of Christ. Jos, Nigeria: Crossroads Media Services.

Walker WO Jr. 1963. Cultus and tradition: A contribution to the problem of faith and history in the Old Testament. PhD dissertation, Duke University.

Wepener, C and Barnard, M. 2016. Worship in the Zion Christian Church (ZCC): A descriptive exploration of a prophetic phenomenon. In $\mathrm{H}$ Kroesbergen (ed.), Prophecy today: Reflections from a Southern African context. Wellington: Christian Literature Fund Publishers, 74-88. 